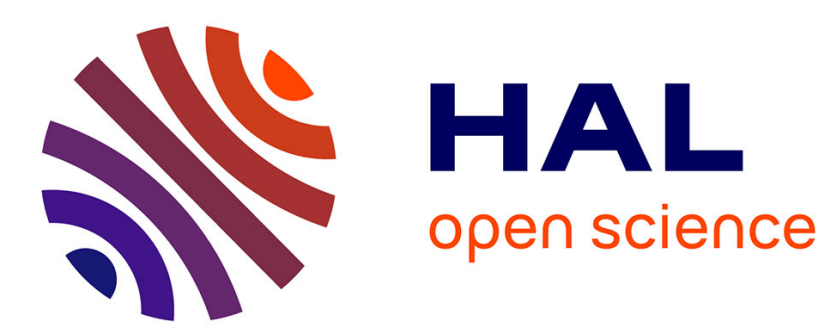

\title{
Comment on the paper in Quaternary International: "Methodological concerns for analysis of phytolith assemblages: Does count size matter?" (C.A.E. Strömberg)
}

\author{
Anne Alexandre, L. Bremond
}

\section{To cite this version:}

Anne Alexandre, L. Bremond. Comment on the paper in Quaternary International: "Methodological concerns for analysis of phytolith assemblages: Does count size matter?" (C.A.E. Strömberg). Quaternary International, 2009, 193 (1-2), pp.141 - 142. 10.1016/j.quaint.2008.03.015 . hal-01909593

\section{HAL Id: hal-01909593 https://hal.science/hal-01909593}

Submitted on 14 Dec 2018

HAL is a multi-disciplinary open access archive for the deposit and dissemination of scientific research documents, whether they are published or not. The documents may come from teaching and research institutions in France or abroad, or from public or private research centers.
L'archive ouverte pluridisciplinaire HAL, est destinée au dépôt et à la diffusion de documents scientifiques de niveau recherche, publiés ou non, émanant des établissements d'enseignement et de recherche français ou étrangers, des laboratoires publics ou privés. 
Provided for non-commercial research and education use. Not for reproduction, distribution or commercial use.

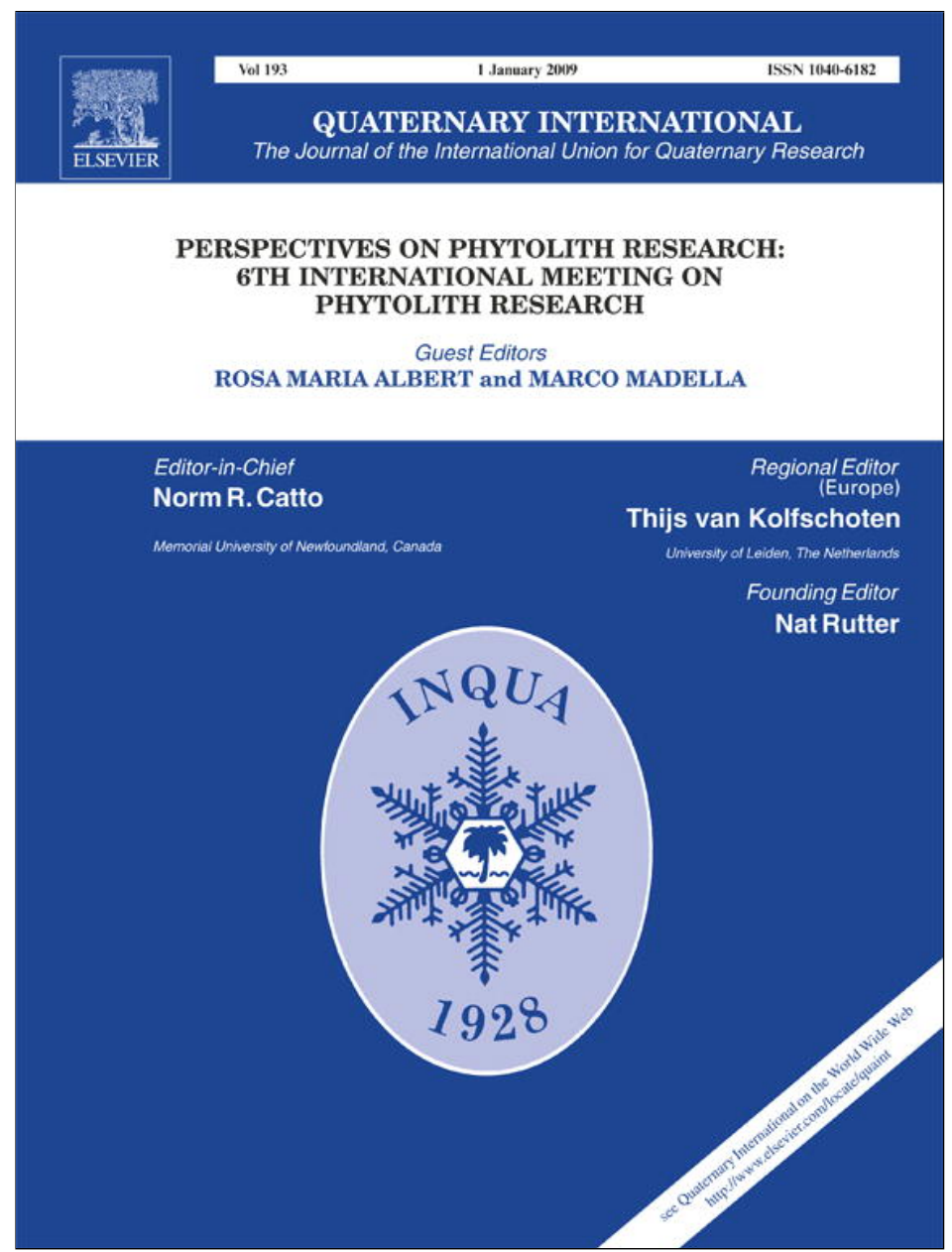

This article appeared in a journal published by Elsevier. The attached copy is furnished to the author for internal non-commercial research and education use, including for instruction at the authors institution and sharing with colleagues.

Other uses, including reproduction and distribution, or selling or licensing copies, or posting to personal, institutional or third party websites are prohibited.

In most cases authors are permitted to post their version of the article (e.g. in Word or Tex form) to their personal website or institutional repository. Authors requiring further information regarding Elsevier's archiving and manuscript policies are encouraged to visit:

http://www.elsevier.com/copyright 


\title{
Comment on the paper in Quaternary International: "Methodological concerns for analysis of phytolith assemblages: Does count size matter?"' (C.A.E. Strömberg)
}

\author{
A. Alexandre ${ }^{\mathrm{a}}$, L. Brémond ${ }^{\mathrm{b}}$ \\ ${ }^{a}$ CEREGE, UPCAM, CNRS, Europôle Méditerranéen de l'Arbois, B.P. 80, 13545 Aix-en-Provence Cedex 04, France \\ ${ }^{\mathrm{b}}$ Center of Bio-Archaeology and Ecology, USTL, EPHE, UMR5059 CNRS, Institut de Botanique, Université Montpellier 2, \\ 163 Rue Broussonet, F-34090 Montpellier, France
}

Available online 27 May 2008

For the last three decades, fossil phytolith assemblages from soils, buried soils and lake sediments have been used, in addition to other vegetation indicators, to reconstruct paleovegetation changes. However, in the objective of strengthening further accuracy for these reconstructions, and in addition to comparison with reference plant collections, recent effort has been made to provide quantitative relationships between modern phytolith assemblages from soils, vegetation and bio-climatic parameters (e.g., Alexandre et al., 1997; Fredlund and Tieszen, 1997; Bremond et al., 2004, 2005a, b, 2008; Blinnikov, 2005; Albert et al., 2006; Lu et al., 2006; Barboni et al., 2007). Along this line, Stromberg (Quaternary International, this volume) presented a paper entitled "Methodological concerns for analysis of phytolith assemblages: Does count size matter?", articulated on (1) calculation of confidence intervals related to count size and (2) investigation on how addition of these confidence intervals may affect vegetation interpretations. The first point is a relevant contribution for increasing accuracy of phytolith data. We comment here on the second point.

For the purpose of her demonstration, the author used published modern phytolith data from West Africa (Bremond et al., 2005a,b) for which she misinterpreted the vegetation significance. The phytolith index $D / P$ was first presented by Alexandre et al. (1997) and later further defined by Bremond et al. (2005a) as the ratio of ligneous dicotyledon phytolith type (globular granulate) characteristic of trees in tropical areas of low elevation, over the sum

E-mail addresses: alexandre@cerege.fr (A. Alexandre), laurent.bremond@univ-montp2.fr (L. Brémond). of Poaceae phytolith types (elongate types excepted). This phytolith index was calibrated, using phytolith assemblages from a forest-savanna transect in Cameroon (Africa), as a proxy of tree cover density or LAI (Leaf Area Index), through a statistical function: $\mathrm{LAI}=(6.97 \pm 2.12 \times \mathrm{D} / \mathrm{P}) /$ $(\mathrm{D} / \mathrm{P}+3.82 \pm 1.96)$ (Bremond et al., 2005a). The explained variance $\left(r^{2}\right)$ was 0.76 and the reproducibility on the measurement of $\mathrm{D} / \mathrm{P}$ was $\pm 6 \%(1 \sigma)$ (calculated from double counting of a same slide $\left(\sigma_{(\mathrm{D} \text { and } \mathrm{P})}= \pm 3 \% ; \sigma_{(\mathrm{D} / \mathrm{P})}= \pm 6 \%\right)$ ).

The authors cautiously did not fix any threshold values of $\mathrm{D} / \mathrm{P}$ that could be used elsewhere for discriminating vegetation formation such as moist forest, dry deciduous forest, tree savanna or grass savanna (physiognomic delimitation defined by the Yangambi scheme for the classification of African vegetation, CSA (1956) or Boughey (1957)). On the contrary, the authors drew particular attention to geographical and methodological limits of the application of the transfer function. They cautiously note that this transfer function could underestimate the LAI when Palmae phytoliths (globular echinate) are locally present in significant amount and when the proportion of Poaceae parallelipipedal bulliform cell phytoliths does not increase proportionally with Poaceae short cell phytoliths.

The reinterpretation of Bremond et al. $(2005 \mathrm{a}, \mathrm{b})$ by Stromberg contains the following approaches:

(1) Without taking into account the geographical and methodological application limits defined in Bremond et al. (2005a), the author took two D/P values locally measured by Bremond et al. (2005b) and used them as threshold values for interpreting a different modern 
data set (Bremond et al., 2005b) that does not fit the application domain requested for applying the LAI proxy. The second data set from Bremond et al. (2005b) is characterized by abundant parallelipipedal bulliform cell phytoliths from Poaceae that do not increase proportionally with Poaceae short cell phytoliths.

(2) Moreover, the $1.82 \mathrm{D} / \mathrm{P}$ value presented by the author as a general forest/tree-savanna threshold is actually the lowest $\mathrm{D} / \mathrm{P}$ value locally measured for the Rinorea and Albizia forests by Bremond et al. (2005a). Instead, when using the transfer function (Bremond et al., 2005a), D/P values that make the local boundary between the shrub and tall grass savanna $(\mathrm{LAI}<1.2)$ and the Rinorea and Albizia forests (LAI > 2.68) range from 0.8 to 2.4. Again without using the calibrated transfer function, the author arbitrary chose a $\mathrm{D} / \mathrm{P}$ value of 0.6 , locally measured for the shrub and tallgrass savanna, as a general threshold value between shrub or tree savanna and savanna.

The use of these approaches makes the re-interpretation of the original phytolith data from Bremond et al. (2005a, b) erroneous and misleading.

Any overview of the studies calibrating the relationships between phytolith, vegetation and climate data indicates a basic limit, inherent to the phytolith tool: because of (1) multiplicity and redundancy in phytolith production, (2) different phytolith productivity from one taxon to another, (3) different phytolith productivity inside a given taxon, whatever its assigned rank is, and (4) selective dissolution or fragmentation of phytoliths in litters and soils, in relation to different environmental conditions, each calibration, and each relationship must be used with caution when applied to other application domains and to discontinuous records. Increasing development of quantitative calibrations for different vegetation types from different regions and different continents are needed for further constraining the use of phytolith assemblages to reconstruct past vegetation changes.

\section{References}

Albert, R.M., Bamford, M.K., Cabanes, D., 2006. Taphonomy of phytoliths and macroplants in different soils from Olduvai Gorge (Tanzania) and the application to Plio-Pleistocene palaeoanthropological samples. Quaternary International 148 (1), 78-94.

Alexandre, A., Meunier, J.-D., Lézine, A.-M., Vincens, A., Schwartz, D., 1997. Phytoliths indicators of grasslands dynamics during the late Holocene in intertropical Africa. Palaeogeography, Palaeoclimatology, Palaeoecology 136, 213-219.

Barboni, D., Bremond, L., Bonnefille, R., 2007. Comparative study of modern phytolith assemblages from inter-tropical Africa. Palaeogeography, Palaeoclimatology, Palaeoecology 246, 454-470.

Blinnikov, M.S., 2005. Phytoliths in plants and soils of the interior Pacific Northwest, USA. Review of Palaeobotany and Palynology 135 (1-2), 71-98.

Boughey, A.S., 1957. The physiognomic delimitation of West African vegetation types. The West African Science Association 3 (2), $148-165$.

Bremond, L., Alexandre, A., Vela, E., Guiot, J., 2004. Advantages and disadvantages of phytolith analysis for the reconstruction of Mediterranean vegetation: an assessment based on modern phytolith, pollen and botanical data (Luberon, France). Review of Palaeobotany and Palynology 129 (4), 213-228.

Bremond, L., Alexandre, A., Hély, C., Guiot, J., 2005a. A phytolith index as a proxy of tree cover density in tropical areas: calibration with Leaf Area Index along a forest-savanna transect in southeastern Cameroon. Global and Planetary Change 45 (4), 277-293.

Bremond, L., Alexandre, A., Peyron, O., Guiot, J., 2005b. Grass water stress estimated from phytoliths in West Africa. Journal of Biogeography 32 (2), 311-327.

Bremond, L., Alexandre, A., Wooller, M.J., Hély, C., Schäfer, P.A., Majule, A., Guiot, J., 2008. Phytolith indices as proxies of grass subfamilies on East African tropical mountains. Global and Planetary Change 61, 209-224.

CSA, 1956. Phytogeography. Scientific Council for Africa South of Sahara (CCTA), Yangambi.

Fredlund, G., Tieszen, L.T., 1997. Calibrating grass phytoliths assemblages in climatic terms: application to the late Pleistocene assemblages from Kansas and Nebraska. Palaeogeography, Palaeoclimatology, Palaeoecology 136, 199-211.

Lu, H.-Y., Wu, N.-Q., Yang, X.-D., Jiang, H., Liu, K.-B., Liu, T.-S., 2006. Phytoliths as quantitative indicators for the reconstruction of past environmental conditions in China. I: Phytolith-based transfer functions. Quaternary Science Reviews 25 (9-10), 945-959. 